上の投薬を受けていた27名と年令, 性, 血圧水準, その 他の検查成績を一致させた比較可能な未治療対照者27名 を選んで両群を比較すると, 未治療群からは11名, 即 ち, 脳出血 6 例, 脳軟化 5 例が発症していたのに対し, 治療群からはくも膜下出血の 1 例のみが発症したにすぎ ない事実が判明した. 又，更に，10年間の追跡期間を前 期, 後期に 2 分して, 各期間の脳卒中その他の主要死因 別死亡率を算出して比較してみると, 心臓病, 癌, 肺炎 等の死亡率には殆んど変化を認めなかったのに対し, 男 子の脳出血死亡率は後期には前期の約 $1 / 4$ 亿低下し, 脳硬 塞死亡率す減少傾向が認められた。乙れは反復した検診 による高血圧者の発見と治療への指導, 本人の自覚によ る生活上の節制その他の総合効果と考えられたが，脳卒 中の予防，殊に最も危険な壮年者を襲う脳出血の予防の 可能性を確立したものと考えている.

わが国のみでなく，英国，米国でも私共の報告と相前 後して高血圧者に対する降圧剤投与による心血管疾患の 予防効果が確認され，報告されている．欧米に多い心臟 疾患に対しては，血圧のコントロールによって必ずしも 効果を認めなかったが，欧米の脳卒中の大部分を占める 脳硬塞には明らかな予防効果が認められた。

日本人の脳卒中にとっては幸運なととに，脳出血は勿 論, 脳硬塞にも予防効果が充分期待できると云える. 只 し, 発見が遅れて既に脳動脈の强状硬化が進展した場合 にも効果があるか否かの確証はないので，現時点ではで きるだけ早期に高血圧を発見して，その後確実な血圧の コントロールを続けるととが, 脳卒中予防の最も実際的 効果的な方法と云えよう.

脳卒中は自分自身の責任で予防できる疾患であるこ とが明らかとなった点を強調し，血圧のコントロールに よって脳卒中を未然に防ぎ, 自身はもとより家族, 親 類，その他の周囲から脳卒中を無くすようお願い致した い.

\section{3. 市板コンポジットレジンの応力緩和について}

\section{○寺下正道・井上勝一郎（理工）}

主として前曾部の修復材として用いられているコンポ ジットレジンは従来のレジンと比較して硬さ，耐摩耗 性, 熱膨張などの性質が政善され囦苳部の修復などにも 使用可能であるといわれているが，その粘弾性的性質に ついての研究は比較的少ない，そてで演者らは現在臨 休で良く使用されている市販コンポシットレジン 5 種

(Adaptic, Concise, Epolite, Palakav, Shof $u$
Composite)，当教室で試作したコンポジットレジン 1 種（粉末にはトリクロールビニルシランで表面処理を行 ったガラス粉末, 液には架橋㓮 EDMA を添加したMM A), 計 6 種について応力緩和を測定し，その水中なら びに空気中における粘弾性挙動を比較検討した。

市販品はメーカーの指示通りに操作し, 試作レジンは $\mathrm{L} / \mathrm{P}=1 / 2$ で混和した.

各試料の粉末あるいはフィラーの重量平均粒度は Shofu Composite $15 \mu$, Concise 16 $\mu$, Epolite $19 \mu$,

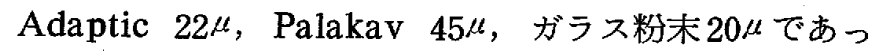
た.

データ解析は（10秒後の緩和弾性率）- (温度) 曲線 とてれを図上微分して得られた曲線とで行った。てれに よると緩和弾性率, 分散温度とも試料汇よりかなりの差 が見られた．それらは 3 種に大別される.すなわち分散 が小さく高温側 $\left(120 \sim 140^{\circ} \mathrm{C}\right)$ でも緩和弾性率の低下 が少なく $10^{10} \mathrm{dyne} / \mathrm{cm}^{2}$ 台を維持するもの（Epolite， 試作レジン), 分散が中程度で高温側での緩和弹性率が $10^{9} \mathrm{dyne} / \mathrm{cm}^{2}$ 台まで下がるもの（Shofu Composite， Concise, Adaptic), 分散が大きく高温側での緩和弾性 率が $120^{\circ} \mathrm{C}$ ずすでに $10^{8} \mathrm{dyne} / \mathrm{cm}^{2}$ 台に下がるもの(Palakav) である.乙れはフィラ一の種類, 量, 大きさ, 特 に基材の種類の相違を反映していると見るととができ る. 水中では空気中に比べて緩和弾性率, 分散温度とも 低い值を示した．乙れは試料中に吸収された水分が可塑 剤として働き分子が流動しやすくなったためと思われ る。

\section{4. 歯科用修復材料に対する各種局所憈布弗化物の影響 （第 3 報）色調変化について}

$$
\text { ○松本仁志・佐伯栄一（口衛） }
$$

フッ化物溶液を雷面塗布し，酤蝕を予防する方法は， 従来より広く応用されている方法である。術式も一般法 の外にトレー法, イオン導入法があり,一般法の局所塗 布に用いられるフッ化物は $2 \% \mathrm{NaF} ， 8 \% \mathrm{SnF}_{2}$, 酸性 弗素リン酸溶液 (APF) が使用されている.

フッ化物溶液が口腔内の曾科修復材に対して如何なる 影響を与えるかというととに興味を持ち，本実験を行な っているが前回までは, 各種フッ化物溶液が歯科用陶材 に対して侵蝕作用を及ぼすととを報告したが。そ後, 陶材の色に対してどの様な変化を及ぼすかについて島津 製光電比色計を用いて測色を行なった。

方法： $2 \% \mathrm{NaF}, 8 \% \mathrm{SnF}_{2}, \mathrm{APF}$ の各溶液に崡科用 
陶材の CERAMCO, ALUMINOUS, VITADUR, JELENKO， SHOFU-Metal Bond のエナメル及びデ

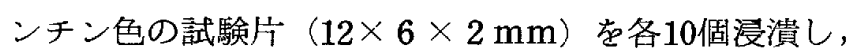
$37^{\circ} \mathrm{C}$ 恒温中に設置， 1 時間後にその測色を行なった . 表色には C.I.E.標準表色系, 即ち XYZ 表色系を用い た。

\section{成績及びまとめ}

フッ化物溶液にて 浸潰する前の Control 群に比較し て, 実験群はエナメル色陶材, デンチン色陶材共に, 明 度が高くなり，彩度が低下していた。

また,フッ化物溶液の陶材に及ぼす侵能作用は, APF $8 \% \mathrm{SnF}_{2}, 2 \% \mathrm{NaF}$ 順に強かった。

\section{5. 费化物酸等取扱い工場就業者の健康調查（第 1 報） 歯科的検診について}

\section{○佐伯栄一・松本仁志 (口衛) 西坂康之（門司労災）}

近年, 産業の急速な発展に伴って新化学物質や技術, 作業環境や作業方法に変化をきたして, 就業者に健康障 害をもたらすことが少なくない，産業衛生においては， 識業病は一般に長期にわたり直接に就業した結果とし て，全身的おるび局所的に発症する特有な疾病であると されている。菌科領域においては, 口腔粘膜の炎症, 橉 の酸蝕症をはじめとして骨におよぶ障害がみられる。

演者らは，作業環境が弗素化合物や酸，アルカリ類の 刺激性粉塺やガスに接するA化学工場の就業者, 平均勤 続年数 12 年, $20 \sim 50$ 才の男性 95 名孝 1973年 5 月に調查検 診を行ない次の結果を得た。

1. 飲料水としての井戸水の弗素濃度は許容量基準内で あった。

2. マスクの使用者は 31 名で，その内で簡易（布）マス クは26名，防毒マスクは5名であった。

3. 平均DMF-Tは9.4本, 平均D-Tは2.7本, 平均 $\mathrm{M}$ $\mathrm{T}$ は1.1本, 平均 $\mathrm{F}-\mathrm{T}$ は5.6本であった。

4. 平均Anterior PMA Indexは, 7.9, 平均 P I は 4.7 , 平均 $\mathrm{M} \mathrm{I}$ は2.7, 平均 $\mathrm{A} \mathrm{I}$ は0.4であった。

5. 㐘牙の白斑は37名に認められ，特に上類小曰崡部に 45.7〜 54.3\%発現していた. また，実質久損は白斑の発 現者のうち16名に認められた。菡肉炎は対照と比較して 有意の差が認められた。

6. 䨑槽骨の $\frac{6}{41} 14$ 部位については, 対照と比較して 骨消失量が強く, 靧骨および頭蓋骨については,トルコ
鞍肥厚, 骨梁粗大, 歯槽骨硬化などが著明であった。 7. 棰液中の弗素含有量は平均 $0.012 \mathrm{ppm}$, 尿中の弗素 量は, 平均 $0.31 \mathrm{ppm}$ であった。

演者らは, 以上の結果から考察して, A化学就業者に みられる菌肉炎, 菌牙の白斑と実質欠損, 畨槽骨执よ゙ 顎骨と頭蓋骨にみられるX線所見の変化は, 乙の程度の 検彰では断定できないが，弗素化合物を主にした物質 によりある程度の影響を受けていることが推察され た.

\section{6. ヒトの下額小曰歯における形態的安定度についての 研究（第 1 報）下影小臼菌の形態観察}

\section{○北井三規一・山田博・井本広暨（口解）}

下額小曰荬は第 1 小曰歯と第 2 小曰歯間において, ど ちらが退化が進んでいるか論議され疑問の点もある.今 回, 演者らは下額小曰荬とその隣接歯である犬崡と第 1 大臼崡との関連性を検討しそれらの間の系統発生学的意 義を解明する目的でまず第1段階として性別が判明し，か つ計測ならびに観察に耐えうる下類小曰歯について調査 を試みたのでその結果を報告する，男性の $\overline{4}$ と $\overline{5}$ との大 きさの比較では齒冠長のみが 煩舌径, 根長, 全長とも至が大きい値を示した。姓で は逆に可が大きい值を示したものは煩舌径のみであっ た. 煩側面形態では両崡牙とも五角形のものが多く次に 四角形が多かった。

次に舌側咬頭が歯冠の煩舌的崡軸に対してどの位置に あるかを調查したところ，両小目崡とも近心側に位置し ているものが最も多かった。さらに舌側面観における舌 側咬頭と副咬頭の発達程度の観察の結果では舌側咬頭が 発達しているものは63\%であったが，遠心の副咬頭はほ とんど諗められないものが 4 で63\%， 5 で44\%諗められ た。可では舌側咬頭の発達がかなり弱いものが29\%，5 では舌側咬頭はもちろんよく発達しているが副咬頭の発 達のよいものが $31 \%$ みられた。舌側咬頭の大きさの調査 では 4 は副咬頭を有せず舌側咬頭の大きい型と小さい型 が同数の出現率で, 5 では舌側咬頭がかなり大きいもの が65\%，次に舌側咬頭に副咬頭を備えたものが $30 \%$ を示 した．さらに咬合面拲形態の調查はて 4 では不明瞭な $\mathrm{H}$ 型 が $57 \%$ ，次に明瞭な $\mathrm{H}$ 型が $30 \% ， \overline{5}$ では明瞭なH型が半 数を示した.

犬苜化傾向では可は示すものが $22 \%, \overline{5}$ では全くみら れなかった．また煩側三角隆線については可は認められ るものとそうでないものが約半数であり， 5 は87\%にお 